\title{
INTEGRATION OF MES AND ERP IN SUPPLY CHAINS: EFFECT ASSESSMENT IN THE CASE OF THE AUTOMOTIVE INDUSTRY
}

\author{
Simon Oman, Robert Leskovar, Bojan Rosi, Alenka Baggia
}

Original scientific paper

This study assesses the effects of manufacturing execution systems (MES) and enterprise resource planning (ERP) systems integration in the case of a medium-sized enterprise in the automotive supply chain. An embedded interface was developed to provide bidirectional exchange of messages between the two corresponding databases. Data exchange between the two separate systems is facilitated by an intermediate document (IDoc) message. The effects of MES-ERP integration were assessed based on the value reference model (VRM), which ensures measurable indicators in multiple dimensions. Velocity, costs and assets for two processes were evaluated before and after integration. Positive changes in the selected key performance indicators were measured and confirmed. MES-ERP integration ensures controlled change management in the supply chain (SC) and enables decision-making to be carried out in real time. Based on the findings of the presented scenario, one can reasonably assume that MES-ERP integration positively affects the selected key performance indicators of a SC.

Keywords: enterprise resource planning; integration; manufacturing execution system; supply chain management; value reference model

Integracija MES i ERP sustava u opskrbnim lancima: procjena učinka na primjeru automobilske industrije

Izvorni znanstveni članak

U ovom radu procjenjujemo učinke integracije proizvodnih izvršnih sustava (MES) i cjelovitih poslovnih informacionih sustava (ERP) na primjeru srednje velikog poduzeća u automobilskom opskrbnom lancu. Ugrađeno sučelje razvijeno je za uspostavu dvosmjerne razmjene poruka između dvije baze podataka. Razmjena podataka između dva odvojena sustava realizirana je putem posebnog dokumenta - IDoc poruke. Učinci integracije MES i ERP procijenjeni su na temelju referentnog vrijednosnog modela (VRM), koji osigurava mjerljive pokazatelje u više dimenzija. Brzina, troškovi i imovina dva procesa procijenjeni su prije i poslije integracije sustava. Pozitivne promjene odabranih ključnih pokazatelja uspješnosti izmjerene su i potvrđene. Integracija MES i ERP osigurava kontrolirano upravljanje promjenama u opskrbnom lancu (SC) i omogućuje donošenje odluka u stvarnom vremenu. Na primjeru nalaza predstavljenog scenarija, utemeljeno možemo pretpostaviti, da integracija sustava MES i ERP pozitivno utječe na odabrane ključne pokazatelje uspješnosti u opskrbnom lancu.

Ključne riječi: cjeloviti poslovni informacijski sustav; integracija; proizvodni izvršni sustav; referentni vrijednosni model; upravljanje lancem opskrbe

\section{Introduction}

The continual changes in the automotive market generally decrease prices and demand a high level of flexibility in small- and medium-sized enterprises (SMEs). According to He and Lai [1], the majority of research to date has studied the importance and role of integration in the supply chain (SC) aimed at improving responsiveness. Supply chain integration (SCI) simultaneously influences different types of company performances [2]. According to [3], manufacturing systems are complex objects with many integrating factors and internal relations. Hence, the need for integration between manufacturing software and business applications is also growing [4-6].

In the context of the $\mathrm{SC}$, in the literature the term "integration" is often related to applications that enable the exchange of documents between partners [7]. A number of researchers have recently claimed that SC vulnerability has become critical due to disruptions and other issues related to measurement and management [8]. Although Childerhouse and Towill [9] found that the depth of SCI correlates significantly with increased performance, in practice the majority of SCs are not well integrated. Numerous studies [10] have shown that information sharing plays a key role in achieving smooth SC functioning. The results of information sharing include: faster coordination between partners, a reduction of uncertainty in internal and external environments, faster material flow, a shorter order cycle time, a reduction in inventory costs [11] and a contribution to overall cost and service-level performance.
All the literature presented to date has a general focus on shared information, encompassing areas such as the scope of information and the frequency and up-to-date nature of information sharing, as well as when, how, and with whom information is shared [10]. Among others, [11] found that effective information sharing and SC practice have a significant influence on delivery performance. Although various practical problems preventing SC linking in the real world are identified [9], many researchers found that the integration of different information systems results in better information sharing within the SC [12], while others [13] provide key findings aimed at overcoming such problems. According to Huo [2], internal integration improves external integration, while internal and external integration directly and indirectly enhances company performance. Indeed, the need to strengthen the external and internal alignment of the manufacturing function and thereby improve business performance was emphasised, while [14] also enhanced his previous research on SCI by linking it to operational and financial performance.

Although enterprise resource planning (ERP) has become dominant management software used in manufacturing and distribution systems in a number of industries, various problems associated with its origin and material requirements planning (MRP) are yet to be resolved [13]. Despite the fact that ERP systems provide integration across the entire business system, results show that companies in transitioning economies continue to face challenges in manufacturing execution system (MES)-ERP system integration [15, 16]. Increasingly, companies are opting for integral solutions that allow 
monitoring and tactical decision-making to be carried out in real time. Manufacturers realised the need for integration when they found that SC monitoring in the ERP system differed from the real situation taking place in production. Transaction systems such as ERP do not detect various events (standstills, scrap, actual cycle time, etc.) in real time and are not recorded as such in the MES. For this purpose, various software solutions (interfaces, add-ons and stand-alone applications) were developed that are aimed at allowing manufacturers to establish links between the business and process domains. Several different approaches are commonly used to establish this link. For example, the ISA S-95 standard is widely used as a base in integration solutions [8], with the Businessto-Manufacturing Markup Language (B2MML) defining the schema that implements such ISA S-95 models [17]. As presented by [18], the adoption of service-oriented architecture (SOA) in all different aspects of the production environment can also bring major advantages when deploying and managing a reconfigurable SC.

In this paper, we present a study of MES-ERP integration aimed at identifying the exact measurable benefits of this integration. Although the effects of information sharing on overall company or SC performance were investigated by several authors [19] and despite the fact that integration is generally considered beneficial to enterprises [20], there remains a lack of research measuring the exact impact of MES-ERP integration on the performance of internal processes. In the present work, we will assess the effects of integration and information sharing in the SC and compare them with previous research findings in this domain. Based on gathered information [21], we critically assess the evidence that MES-ERP integration in the SC has a significant impact on defined performance indicators in the key SME's internal processes, with a further impact on the entire SC.

The paper is organised as follows: in Section 2 the research questions are defined; Section 3 includes a brief presentation of the mechanism used in integrating the MES and ERP as well as the methodology employed in assessing the implemented MES-ERP integration; Section 4 presents the results of research involved in the MES-ERP integration procedure and the evaluation of the implemented MES-ERP integration; the discussion is presented in Section 5 and conclusions in Section 6, with guidelines for future research, given at the end.

\section{Research questions}

This particular study of MES-ERP integration focuses on the interface development and measurement of the effects of integration. Furthermore, based on the literature discussing the efficiency of internal integration in the $\mathrm{SC}$, we argue that the effects of integration are rarely quantitatively expressed. Therefore, at least three important questions arise:

\section{RQ1: Which concepts are used in developing MES-ERP integration?}

Members of the selected automotive cluster of Slovenia identified the need to integrate MES and ERP systems in order to provide efficient and up-to-date information across the entire SC. Although several solutions for
MES-ERP integration exist, none of those available is appropriate for the integration of the HYDRA MES and Microsoft Dynamics NAV ERP systems. Due to the lack of program libraries in the Microsoft Dynamics NAV ERP system that allow a MES-ERP interface to be created, requirements were set which enable the development, testing, and implementation of a complete user-friendly graphical interface for MES-ERP integration

RQ2: How should the impact of MES-ERP integration on the production process be measured?

The direct and indirect impacts of internal and external integration in a SC are linked to diverse aspects of process performance. An appropriate framework with which to evaluate the performance and efficiency of the transformation of business processes must therefore be selected and key performance indicators defined.

RQ3: What are the relative changes in velocity, costs and assets in the ordering and planning processes?

Generally, business and production processes are measured in terms of velocity, costs and assets. Ordering and planning processes are connected; delayed data exchange among and between these processes thus causes lower responsiveness, increased costs and decreased assets. The following sections present the development of the MES-ERP integration graphical user interface (GUI) and subsequent assessment of the implemented MESERP integration.

\section{Methodology}

Some studies assumed that anyone who implements a given collection of integrative mechanisms or practices is equally likely to enjoy the resulting performance benefits [22]. In contrast, the goal of the present research was to establish the relative change and extent to which MESERP integration impacts the selected performance indicators. MES-ERP integration, which enables bidirectional exchange, was implemented using a software interface embedded into the ERP system. The data integration mechanism described in this paper is commonly used in the industry and is proven to be stable.

MES-ERP integration was followed by an assessment of its effects. Identified key performance indicators (KPIs) in the value chain (VC), as proposed by the Value Reference Model (VRM), were measured in the observed enterprise. The VRM presented by the Value Chain Group [23] was used to construct metrics for two main reasons: (a) the model provides an accurate description of indicators [24] and (b) it enables future application in virtual enterprise environments, an approach that tackles innovation processes in collaboration networks [25]. The ordering and planning processes, identified as the key critical processes for efficient data flow, were evaluated based on three dimensions (KPIs): velocity, costs and assets.

Measurement data were obtained before and after integration, including the sending and receiving of data from 56 members of the selected automotive cluster. The 
measurements and metrics selected in the presented analysis aimed at supporting the understanding of how ERP-MES integration affects ordering and planning processes.

\subsection{Integration of MES and ERP}

The leading standardisation organisations in the domain of manufacturing integration, the International Society of Automation (ISA) and the Manufacturing Execution Solutions Association (MESA), have put considerable effort into finding a common definition for specifying generic MES functionality. The integration of MES and ERP requires middleware or an interface for data exchange between the manufacturing process and business domain [26]. The ISA S-95 standard helps automation professionals to streamline processes and improve industry standards for vertical integration between MES, ERP and the shop-floor level [27].

Although various requirements regarding MES and ERP integration were examined previously [28], the presented approach is based on intermediate document (IDoc) messages. IDoc represents a structured form of record for the transfer of messages (data) from SAP (German: Systeme, Anwendungen, Produkte) to other systems and vice versa. A Remote Function Call (RFC) in SAP NetWeaver enables the user to integrate SAP and MES. However, the shortcoming of this approach is that development libraries are only available for the SAP environment. For the Microsoft Dynamics NAV used in this research, development libraries such as SAP are not available. Therefore, the Client/Application Language (C/AL), which is part of the Microsoft Dynamics NAV client/server integrated development environment (C/SIDE), was used to embed the GUI for inbound and outbound IDoc messages. Various segments define the format and structure of a data record in IDoc. The developed GUI was designed to connect the MES to the guiding or leading ERP system. In this context, the words "guiding" and "leading" describe the ERP system's position at the upper hierarchy level, where production orders, including their operations and manufacturing of Bills Of Materials (BOMs), are derived from strategic planning processes (MRP, MRPII, etc.). The base information is then generated within the ERP system and finally sent to the MES. The MES is therefore the "receiving" system and follows the leading or guiding ERP system. The GUI covers the following requirements:

- Standard interface for the takeover of default order data from the ERP system ("download"), as well as for the confirmation of shop-floor feedback postings from the MES to the ERP system ("upload");

- Rollout-capable and compatible solution;

- Tight interfacing of MES and ERP in order to meet the requirements of the integrated solution's increasing sensitivity;

- Maintainability and administration of the interface.

Various standards are developed as tools for the exchange of information between different applications. MESA [29] originally identified 11 functions or activities as part of MES but since have expanded to the current model that describes the information system relationships used to support company objectives ranging from plant floor to company-wide strategic initiatives. The approach of the ISA is based on ISA S-95, the international standard for the integration of enterprise and control systems. ISA S-95 describes a three-level structure comprising business planning and logistics, Manufacturing Operations Management (MOM) and the actual automation level. Although standardisation and integration is a significant development trend in new research examining MES, the ISA standard focuses more on interfaces and vertical integration between MES, ERP and shop-floor layers [27]. Transferring information manually from one system to the other takes both time and effort. Moreover, human users are prone to mistakes, while well-tested interfaces are not. Kletti [26] identified four contrasting approaches to data transmission handled by different interfaces between MES and ERP systems: database-to-database, file-based, web services, RFC and IDoc. With regard to the present goal of MES-ERP integration in the automotive industry, we used the RFC and IDoc method. In this approach, conditions were imposed to ensure that IDoc and SAP proprietary data could be used for exchange with non-SAP applications. The bidirectional data exchanges that take place between MES and ERP are illustrated in Fig. 1.

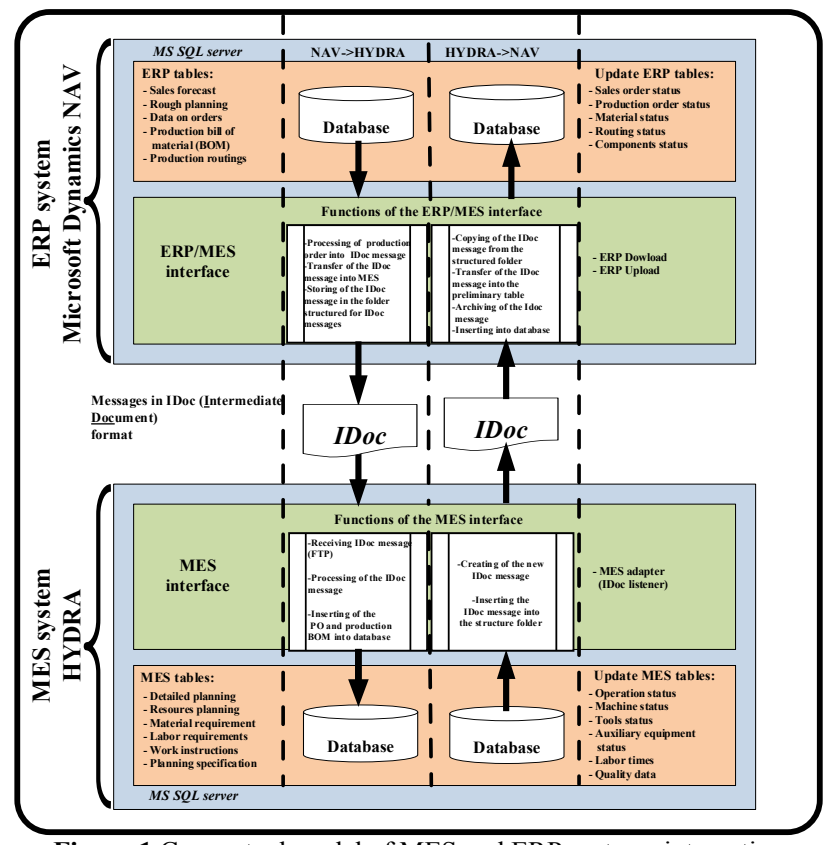

Figure 1 Conceptual model of MES and ERP systems integration

In this architecture, the ERP system contains all the necessary order-related data for calculations in both MRP and Master Production Scheduling (MPS). Production orders are based on actual customer orders and sales forecasts. Relevant production routings and manufacturing BOMs, as well as the corresponding delivery dates, are also considered. The ERP embedded interface transfers data from the ERP system through standardised IDoc messages and ensures that the IDoc record has a valid structure. The MES interface then receives the message, processes it and returns the standardised IDoc messages to the ERP. Triggers for message transfers can be either semi-automatic (including operator demand, end of shift and various other events 
that take place during the production process, such as maintenance of production resources and set-up changes) or automatic (such as services running on the Navision application server). Cycle times, number of items produced, standstills and scrap are all reported by the MES, both on operator demand and in real time.

\subsection{Assessment of the implemented MES-ERP integration}

In order to evaluate the potential impact of the improved implemented MES-ERP integration, we firstly analysed existing related scientific papers in the literature (e.g., [27]), as well as white papers from various associations within the manufacturing industry (e.g., [30]) and research models. The next two steps involved summarising metrics from members of automotive suppliers, followed by relationship design between the summarising metrics and research models.

The Supply Chain Operations Reference (SCOR) model and VRM are the two most comprehensive and widely adopted reference models. Originally designed for effective communication among SC partners, the SCOR model is a reference model incorporating elements including the standard description of processes, standard metrics and best-in-class practices [31]. In contrast, the VRM adopts a more integrative approach and supports an integrated framework that covers enterprise management, product development, SCI and customer relationship management. In summary, the VRM is a more comprehensive method than SCOR. Nevertheless, both models include a KPI dictionary that is essentially a list of KPI definitions, properties and relationships with goals and processes [32]. Prior to the present analysis, an examination was made of both reference models and after several intensive discussions it was decided that the VRM would be used due to its ability to enable an integrative framework approach to the definition of measurable KPIs regarding MES-ERP integration in the automotive industry.

As mentioned above, the assessment of the implemented MES-ERP integration is based on KPIs [33]. These indicators are important not only for the optimisation of internal company processes but also for the entire SC [34]. Evaluation of MES-ERP integration in the SC included the following steps: (a) selection of VRM processes; (b) definition of VRM priority dimensions; (c) identification of performance indicators and (d) evaluation of process improvements.

In the present study, ordering and planning processes in the SC were selected, as these two processes provide crucial data for the evaluation of business results. Process VRM names were assigned as PS1 (gathering of SC requirements) and PS4 (creation of SC plan), with the following priority dimensions defined: velocity, cost per unit and assets, defined as the average percentage per unit sold. KPI metrics identified in the ordering process were as follows:

- Velocity expressed in days or hours: on-time delivery of products, delivery cycle time of material, production cycle time, interval of sale forecasts and order fulfilment cycle time;

- Costs expressed in euros: costs of delivery performance, costs of ordering documents;
- $\quad$ Assets expressed as average percentage per unit sold: costs of defective orders, costs of rework production and costs of SC flexibility.

In the planning process, the following KPI metrics were selected:

- Velocity expressed in days or hours: cycle time of production querying, cycle time of forward planning, interval of production forecasts, cycle time of production planning, and delivery cycle time of production;

- Costs expressed in euros: costs of defective documents;

- $\quad$ Assets expressed as average percentage per unit sold: costs of defective components, logistics costs, costs of delivery ratio and warehousing costs.

Evaluation of improvements in the processes was based on a comparison of the results obtained prior to and after MES-ERP integration. The measurable indicators essentially consist of metrics, which can be combined in individual dimensions of velocity, cost and assets. The velocity dimension represents the average time interval that an individual unit requires to complete a cycle through the process (cycle time). Velocity metrics are measured in terms of a unit of time (hour, day) and include the average cycle of ordering and planning processes. The cost dimension evaluates those measured values related to the costs generated in the ordering and planning processes and represents the average cost assigned to the logistics process, rework and inventory stock. Finally, the asset dimension represents the overall evaluated current assets (working capital) and is expressed as average percentage per unit sold.

\section{Results}

An embedded GUI in the Microsoft Dynamics NAV ERP system was developed based on the following core procedures of MES-ERP integration: (a) exchanging messages between the ERP and MES (NAV to HYDRA) and (b) exchanging messages between the MES and ERP (HYDRA to NAV).

The main functions of the interface include: creating valid IDoc messages on the ERP side; picking up IDoc messages on the MES side; bidirectional transfer of IDoc messages via file transfer protocol between ERP and MES host computers; processing of IDocs (creating and deleting files in dedicated directories on both ERP and MES sides); manipulating the corresponding records of dedicated ERP and MES database tables (inserting, updating, and deleting) and creating and maintaining triggers for IDoc message transfer. In this way the approval of data received from the HYDRA MES system and the subsequent saving of these data in the database of the Microsoft Dynamics NAV ERP system is performed.

The information flow in the MES-ERP integration is formed by the upper hierarchy level, which in the ERP system contains all the necessary order-related data. Firstly, the ERP embedded interface picks up metadata from the Microsoft Dynamics NAV ERP system database. After data conversion (interpretation) in IDoc messages and data translation according to the IDoc schema, the 
message is received by the MES middleware layer, which treats IDoc messages as its gateway (starting points) and converts them into a form that the HYDRA MES application can process. The HYDRA MES then provides data acquisition under Shop Floor Control (SFC) via a data collection terminal. The data accumulated over shifts are prepared correspondingly and are available to the corporate ERP system. The MES transfers aggregated data to the ERP system via the ERP embedded interface, which picks up structured IDoc messages from the MES middleware layer and sends IDocs into the ERP middleware layer. Data conversion (interpretation) from structured IDoc records to Microsoft Dynamics NAV ERP system format is then triggered. Data received from the HYDRA MES are arranged according to manufacturing type (batch, continuous, or discrete) in the Microsoft Dynamics NAV ERP system application and are summarised in an output journal. The approval of the data received from the HYDRA MES and their subsequent saving in the Microsoft Dynamics NAV ERP system database are performed at the end of the process.

\subsection{Evaluation of implemented MES-ERP integration}

The terms "achieved benefits" $(B)$ and "overall savings" $(S)$ are typically mentioned from an economic perspective. Frequent assessment of benefits and savings enable necessary changes in organisational structure, strategies and processes [35]. The improved performance of the implemented MES-ERP integration is here attributed to the two VRM processes (PS1 and PS4).

Tab. 1 presents selected metrics, expected improvements offered by MES-ERP integration and actual values before and after integration. The data used to calculate values before and after integration were aggregated from Excel files exchanged between members of automotive suppliers. Data exchange between SC partners was conducted once a day via email, with each SC partner providing a large Excel file that was also distributed to all other SC partners. Members of the automotive suppliers and key customers set expected improvements. In order to simplify the determination of the actual benefits of MES-ERP integration, the achieved benefits $(\mathrm{Bi})$ were calculated based on values recorded after integration (VAI) and before integration (VBI), as presented in Eq. (1):

$$
B_{i}=\left(1-\frac{V A I_{i}}{V B I_{i}}\right) * 100
$$

where $i$ is a specific metric.

Table 1 Measurements of key performance indicators before and after integration

\begin{tabular}{|c|c|c|c|c|c|c|c|}
\hline $\begin{array}{l}\text { VRM } \\
\text { process }\end{array}$ & $\begin{array}{l}\text { Process } \\
\text { description }\end{array}$ & $\begin{array}{l}\text { Dimension } \\
(j)\end{array}$ & $\begin{array}{l}\text { Metric } \\
\text { (i) }\end{array}$ & Unit & $\begin{array}{l}\text { Expected } \\
\text { benefit }\end{array}$ & $\begin{array}{l}\text { Value before } \\
\text { integration }\end{array}$ & $\begin{array}{l}\text { Value after } \\
\text { integration }\end{array}$ \\
\hline \multirow[t]{3}{*}{$\begin{array}{l}\text { PS1 } \\
\text { (Gather } \\
\text { supply } \\
\text { chain } \\
\text { requirement) }\end{array}$} & \multirow[t]{3}{*}{$\begin{array}{l}\text { Ordering } \\
\text { process } \\
\text { in the } \\
\text { supply } \\
\text { chain }\end{array}$} & Velocity & $\begin{array}{l}\text { on-time delivery of product } \\
\text { delivery cycle time of material } \\
\text { production cycle time } \\
\text { interval of sale forecast } \\
\text { order fulfilment cycle time }\end{array}$ & $\begin{array}{l}\text { day } \\
\text { hour }\end{array}$ & $30 \%-50 \%$ & $\begin{array}{r}24 \text { hours } \\
5 \text { days } \\
11 \text { days } \\
2 \text { days } \\
24 \text { hours }\end{array}$ & $\begin{array}{r}8 \text { hours } \\
3 \text { days } \\
9 \text { days } \\
1 \text { days } \\
8 \text { hours }\end{array}$ \\
\hline & & Cost $*^{a}$ & $\begin{array}{l}\text { costs of delivery performance } \\
\text { cost of order document }\end{array}$ & $€$ & $20 \%-30 \%$ & $\begin{array}{r}8 € \\
67 €\end{array}$ & $\begin{array}{r}6 € \\
50 €\end{array}$ \\
\hline & & Asset $*^{b}$ & $\begin{array}{l}\text { costs of defective orders } \\
\text { costs of rework production } \\
\text { costs of supply chain flexibility }\end{array}$ & $\%$ & $20 \%-30 \%$ & $\begin{array}{r}4.3 \% \\
3.5 \% \\
5 \%\end{array}$ & $\begin{array}{r}3.5 \% \\
2.5 \% \\
3 \% \\
\end{array}$ \\
\hline \multirow[t]{3}{*}{$\begin{array}{l}\text { PS4 } \\
\text { (Create } \\
\text { supply chain } \\
\text { plan) }\end{array}$} & \multirow[t]{3}{*}{$\begin{array}{l}\text { Planning } \\
\text { process in } \\
\text { the supply } \\
\text { chain }\end{array}$} & Velocity & $\begin{array}{l}\text { cycle time of production querying } \\
\text { cycle time of forward planning } \\
\text { interval of production forecast } \\
\text { cycle time of production planning } \\
\text { delivery cycle time of production }\end{array}$ & $\begin{array}{l}\text { day } \\
\text { hour }\end{array}$ & $30 \%-50 \%$ & $\begin{array}{r}11 \text { days } \\
5 \text { days } \\
24 \text { hours } \\
4 \text { days } \\
24 \text { hours }\end{array}$ & $\begin{array}{r}9 \text { days } \\
3 \text { days } \\
8 \text { hours } \\
2 \text { days } \\
8 \text { hours }\end{array}$ \\
\hline & & Cost $* a$ & costs of defective documents & $€$ & $20 \%-30 \%$ & $8 €$ & $6 €$ \\
\hline & & Asset $*^{b}$ & $\begin{array}{l}\text { costs of defective components } \\
\text { logistics costs } \\
\text { costs of delivery ratio } \\
\text { warehousing costs }\end{array}$ & $\%$ & $20 \%-30 \%$ & $\begin{array}{r}6.8 \% \\
2.7 \% \\
6 \% \\
3.2 \% \\
\end{array}$ & $\begin{array}{r}5.5 \% \\
2 \% \\
4 \% \\
2 \%\end{array}$ \\
\hline
\end{tabular}

$*^{a}$ Cost per unit

$*^{b}$ Average percentage per unit sold

Tab. 1 reveals that there were delays in data processing that had an adverse impact on the system, particularly in commercial decision-making and inventory management. The achieved benefits metric includes a framework number of KPIs that are used to quantitatively measure the performance improvement resulting from MES-ERP integration. However, this method lacks a coherent representation of the interdependencies between the different KPIs. In order to close this gap, the weighted average method [36] was employed to calculate overall savings within specific dimensions, as expressed in Eq. (2):

$$
\bar{S}_{j}=\frac{\sum_{i=1}^{n j} B_{j, i}}{n_{j}}
$$

where $i$ is a specific metric, $j$ is a dimension and $n$ is the number of metrics. Tab. 2 presents the achieved benefits $(B j, i)$ and overall savings $\left(S_{j}\right)$ within each dimension for the selected processes. Four metrics address the timeliness of information: order fulfilment cycle time, on-time delivery of product, interval of production forecasts and delivery cycle time of production. The metrics order fulfilment cycle time and on-time delivery of product were 
measured during the ordering process in the SC and are expressed as the time interval of received and submitted ordering information. The time interval of the received order is expressed in the metric order fulfilment cycle time, which is the amount of time required to deliver items. The on-time delivery of orders is expressed in the metric on-time delivery of product, which includes the time interval of the received and submitted realised order. The metrics interval of production forecasts and delivery cycle time of production were measured during the planning process in the SC and are expressed as the time interval of received and submitted planning information. The time interval of the received plan is expressed as the interval of production forecasts, which is the amount of time required to produce items. The on-time generation of the plan is expressed in the metric delivery cycle time of production and represents the time interval of the information submitted regarding the realised plan.

Table 2 Achieved business benefits for each dimension

\begin{tabular}{|c|c|c|c|c|c|c|}
\hline $\begin{array}{l}\text { VRM } \\
\text { process }\end{array}$ & $\begin{array}{l}\text { Process } \\
\text { description }\end{array}$ & $\begin{array}{l}\text { Dimension } \\
\text { (j) }\end{array}$ & $\begin{array}{l}\text { Metric } \\
\text { (i) }\end{array}$ & Unit & $\begin{array}{l}\text { Achieved } \\
\text { benefit }(\boldsymbol{B} j, i)\end{array}$ & $\begin{array}{l}\text { Overall } \\
\text { savings }\left(\boldsymbol{S}_{j}\right)\end{array}$ \\
\hline \multirow[t]{3}{*}{$\begin{array}{l}\text { PS1 } \\
\text { (Gather supply } \\
\text { chain requirement) }\end{array}$} & \multirow[t]{3}{*}{$\begin{array}{l}\text { Ordering process } \\
\text { in the supply } \\
\text { chain }\end{array}$} & Velocity & $\begin{array}{l}\text { on-time delivery of product } \\
\text { delivery cycle time of material } \\
\text { production cycle time } \\
\text { interval of sale forecast } \\
\text { order fulfilment cycle time }\end{array}$ & $\begin{array}{l}\text { day } \\
\text { hour }\end{array}$ & $\begin{array}{l}67 \% \\
40 \% \\
18 \% \\
50 \% \\
67 \%\end{array}$ & $48 \%$ \\
\hline & & Cost $*^{a}$ & $\begin{array}{l}\text { costs of delivery performance } \\
\text { cost of order document }\end{array}$ & $€$ & $\begin{array}{l}25 \% \\
25 \%\end{array}$ & $25 \%$ \\
\hline & & Asset $*^{b}$ & $\begin{array}{l}\text { costs of defective orders } \\
\text { costs of rework production } \\
\text { costs of supply chain flexibility }\end{array}$ & $\%$ & $\begin{array}{l}19 \% \\
29 \% \\
40 \%\end{array}$ & $29 \%$ \\
\hline \multirow[t]{3}{*}{$\begin{array}{l}\text { PS4 } \\
\text { (Create supply } \\
\text { chain plan) }\end{array}$} & \multirow[t]{3}{*}{$\begin{array}{l}\text { Planning process } \\
\text { in the supply } \\
\text { chain }\end{array}$} & Velocity & $\begin{array}{l}\text { cycle time of production querying } \\
\text { cycle time of forward planning } \\
\text { interval of production forecast } \\
\text { cycle time of production planning } \\
\text { delivery cycle time of production }\end{array}$ & $\begin{array}{l}\text { day } \\
\text { hour }\end{array}$ & $\begin{array}{l}18 \% \\
40 \% \\
67 \% \\
50 \% \\
67 \%\end{array}$ & $48 \%$ \\
\hline & & Cost $*^{a}$ & costs of defective documents & $€$ & $25 \%$ & $25 \%$ \\
\hline & & Asset $*^{b}$ & $\begin{array}{l}\text { costs of defective components } \\
\text { logistics costs } \\
\text { costs of delivery ratio } \\
\text { warehousing costs }\end{array}$ & $\%$ & $\begin{array}{l}19 \% \\
26 \% \\
33 \% \\
38 \%\end{array}$ & $29 \%$ \\
\hline
\end{tabular}

$*^{a}$ Cost per unit

$*^{b}$ Average percentage per unit sold

\section{Discussion}

The results presented above provide strong evidence that MES-ERP integration should be an important strategy in the automotive industry, enabling better SC management, the development of joint plans, faster data exchange and the efficient fulfilment of customer requirements.

Among several concepts of MES-ERP integration (RFC, IDoc, proprietary connectors, SOA), IDoc provides loose coupling of heterogeneous systems (RQ1). Impact of MES-ERP integration in the production processes should be measured with valid and established metrics such as VRM (RQ2). Relative changes in velocity, costs and assets (RQ3) are shown in Tab. 1. The 24-hour time interval needed to send an email message from one SC partner to another was significantly shorter after the introduction of the developed interface. Even though no other improvements were made to the system or business process, the introduction of the developed interface shortened the time interval from 24 to 8 hours (one shift) and also reduced the number of double entries and errors. In the ordering process, improvement in the on-time delivery of products, order fulfilment cycle time and costs of SC flexibility all proved to be higher than expected. Only two metrics exhibited a lower level of improvement than expected: production cycle time (18\% improvement) and costs of defective orders (19\% improvement). Similarly, the values of certain planning process metrics were also higher than expected, including the interval of production forecasts, delivery cycle time of production, costs of delivery ratio and warehousing costs. Although still improved, the cycling time of production querying and costs of defective components were both slightly lower than expected.

The lower than expected benefits (for production cycle time, cycle time of production querying and costs of defective components) can likely be explained by ageing and the high utilisation of production technology. On the other hand, the occurrence of human errors during the ordering process significantly affects the improvement of certain other metrics (such as the costs of defective orders). In contrast, some of the higher than expected benefits of integration may be related to metric sensitivity to the frequency of data exchange.

\section{Conclusions}

The effective exchange and synchronisation of data in a SC has an impact on the quality of overall cooperation among companies, particularly if resource allocation is included in their operations. Data integration introduces a new perspective of business cooperation, by which all key processes in the company can be incorporated via an integrated ERP system. In this research, ERP and MES were successfully integrated via the use of Middleware, incorporating IDoc messages and a GUI, embedded in the ERP system, being both user friendly and enabling sufficient control over bidirectional exchange of data between MES and ERP systems. The tested integration 
based on ERP (Microsoft Dynamics NAV) and MES (HYDRA) was deployed in production.

The presented study provides a representative solution that, despite the lack of software libraries on the ERP side, it is possible to implement integration between manufacturing process and business domain. This research also suggests that MES-ERP integration can be generally implemented in an industry environment without the need for software vendor specialised libraries. We believe that a more straightforward implementation of MES-ERP integration can be supported by open-source communities. VRM was selected as a useful tool with which to measure the effects of the implemented MESERP integration. Relative changes in velocity, costs and assets were identified for both the ordering and planning processes. We conclude that the benefits are significant and worth the effort required for MES-ERP integration, with all the observed metrics indicating significant improvements. The data presented here might prove useful for practitioners looking to justify their own MESERP integration projects.

Nevertheless, further research is still required in order to assess the effects of MES-ERP integration at the SC scale. VRM can be used to provide an insight into the benefits of integration for both the entire SC and the virtual enterprise environment, with the latter offering new opportunities for open innovation and therefore enabling an even wider space for the application of diverse solution integrations.

\section{References}

[1] He, Y.; Lai, K. K. Supply Chain Integration and Service Oriented Transformation: Evidence from Chinese Equipment Manufacturers. // Int. J. Prod. Econ. 135, 2(2012), pp. 791-779. https://doi.org/10.1016/j.jpe.2011.10.013

[2] Huo, B. The Impact of Supply Chain Integration on Company Performance: An Organizational Capability Perspective. // Supply Chain Manag.: Int. J. 17, 6(2012), 596-610. https://doi.org/10.1108/13598541211269210

[3] Cerjaković, E.; Topčić, A.; Tufekičić, D.; Veža, I. Influence of structure of manufacturing systems and the amount of investment on production costs. // Tehn. vjesn. 22, 3(2015), pp. -780. https://doi.org/10.17559/TV-20140307103216

[4] Miskon, S.; Fielt, E.; Bandara, W.; Gable, G. Towards a typology of structural arrangements for shared services: evidence from the higher education sector. // Electron. Mark. - Int. J. Netw. Bus. 23, 2(2013), pp. 149-162. https://doi.org/10.1007/s12525-012-0116-0

[5] Aversano, L.; Grasso, C.; Tortorella, M. Managing the alignment between business processes and software systems. // Inform. Software Tech. 72, (2016), pp. 171-188. https://doi.org/10.1016/j.infsof.2015.12.009

[6] Romero, D.; Vernadat, F. Enterprise information systems state of the art: Past, present and future trends. // Comput. Ind. (2016). https://doi.org/10.1016/j.compind.2016.03.001

[7] Wagner, S. M.; Neshat, N. A. Comparison of Supply Chain Vulnerability Indices for Different Categories of Firms. // Int. J. Prod. Res. 50, 11(2012), pp. 2877-2891. https://doi.org/10.1080/00207543.2011.561540

[8] Virta, J.; Seilonen, I.; Tuomi, A.; Koskinen, K. SOA-Based Integration for Batch Process Management with OPC UA and ISA-88/95. // In: Emerging Tecnologies and Factory Automation (ETFA), 2010 IEEE Conf., (2010), pp. 18. https://doi.org/10.1109/ETFA.2010.5641286
[9] Childerhouse, P., Towill, D.: Arcs of Supply Chain Integration. // Int. J. Prod. Researsch. 49, 24(2011), pp. 7441-7468. https://doi.org/10.1080/00207543.2010.524259

[10] Ding, H.; Guo, B.; Liu, Z. Information Sharing and Profit Allotment Based on Supply Chain Cooperation. // Int. J. Prod. Econ. 33, 1(2011), pp. 70-79. https://doi.org/10.1016/j.jpe.2010.06.015

[11] Cheng, J. H. Inter-Organizational Relationship and Information Sharing in Supply Chains. // Int. J. Inf. Manag. 49, 24(2011), pp. 7441-7468. https://doi.org/10.1016/j.ijinfomgt.2010.09.004

[12] Klassen, R. D.; Vereecke, A. Social Issues in Supply Chains: Capabilities Link Responsibility, Risk (Opportunity) and Performance. // Int. J. Prod. Econ. 140, 1(2012), pp. 103-115. https://doi.org/10.1016/j.ijpe.2012.01.021

[13] Ho, C.; Ireland, C. T. Mitigating Forecast Errors by LotSizing Rules in ERP-Controlled Manufacturing Systems. // Int. J. Prod. Res. 50, 11(2012), pp. 3080-3094. https://doi.org/10.1080/00207543.2011.592156

[14] Gonzales-Benito, J.; Lannelongue, G. An Integrated Approach to Explain the Manufacturing Function's Contribution to Business Performance. // Int. J. Oper. Prod. Manag. 34, 9(2014), pp. 1126-1152. https://doi.org/10.1108/IJOPM-08-2011-0297

[15] Bernroider, E. W.; Sudzina, F.; Pucihar, A. Contrasting ERP Absorption Between Trasition and Developed Economies from Central and Easterm Europe (CEE). // Inf. Syst. Manag. 28, 3(2011), pp. 240-257. https://doi.org/10.1080/10580530.2011.58558

[16] Simunovic, G.; Saric, T.; Lujic, R. Application of neural networks in evaluation of technological time. // Strojniski vestnik-Journal of Mechanical Engineering. 54, 3(2008), pp. 179-188.

[17] Power, M.; Wlodarczyk, P. Process Definition Management: Using ISA-88 and BatchML as a Basis for Process Definitions and Recipe Normalization. // In: MESA White Paper (2008).

[18] Cândido, G.; Barata, J.; Colobo, A.; Francois, J. SOA in Reconfigurable Supply Chains: A Research Roadmap. Eng. // Appl. Artif. Intell. 22, 6(2009), pp. 939-949. https://doi.org/10.1016/j.engappai.2008.10.020

[19] Li, M.; Li, H. Research on RFID Integration Middleware for Enterprise Information System. // J. Softw. 6, 2(2011), 167-174. https://doi.org/10.4304/jsw.6.2.167-174

[20] Kähkönen, T.; Maglyas, A.; Smolander, K. What do We Know about ERP Integration? // In: Hammoudi, S.; Cordeiro, J.; Maciaszek, L.; Filipe, J. (eds.) Enterprise Information System, vol. 190, pp. 51-67. Springer International Publishing, Switzerland (2014). https://doi.org/10.1007/978-3-319-09492-2_4

[21] Barratt, M.; Barratt, R. Exploring Internal and Externel Supply Chain Linkages: Evidence from the Field. // J. Oper. Manag. 29, 5(2011), pp. 514-825. https://doi.org/10.1016/j.jom.2010.11.006

[22] Turkulainen, V.; Ketokivi, M. Cross-Functional Integration and Performance: What Are the Real Benefits? // Int. J. Oper. Prod. Manag. 32, 4(2012), pp. 447-467. https://doi.org/10.1108/01443571211223095

[23] Value Chain Group: Introduction to the Value Reference Model (VRM), http://www.value-chain.org/en/cms/1960 (02.01.2013).

[24] Diamantini, C.; Potena, D.; Storti, E. A Logic-Based Formalization of KPIs for Virtual Enterprises. // Lect. Notes Bus. Inf. Process. (2013), pp. 274-285. https://doi.org/10.1007/978-3-642-38490-5 26

[25] Knoke, B.; Eschenbächer, J. Virtual Enterprise Environments (VEEs) to Enable Innovation in Collaborative Networks - Initial Modelling Approach. // IFIP Adv. Inf. Commun. Technol. 380, (2012), pp. 616623. https://doi.org/10.1007/978-3-642-32775-9_61 
[26] Kletti, J. MES - Manufacturing Execution System: Moderne Information Technologie zur Prozessfähigkeit der Wertschöpfung. Springer-Verlag, Berlin/Heidelberg, Germany (2006). https://doi.org/10.1007/3-540-28011-1

[27] Schmidt, A.; Otto, B.; Österle, H. A Functional Reference Model for Manufacturing Execution Systems in the Automotive Industry. // Wirtschaftsinformatik Proc. 2011. Paper 89 (2011)

[28] Fang, J.; Huang, G. Q.; Li, Z. Event-driven multi-agent ubiquitous manufacturing execution platform for shop floor work-in-progress management. // Int. J. Prod. Res. 51, 4(2013), pp. 1168-1185 https://doi.org/10.1080/00207543.2012.693644

[29] MESA: MES Explained: A High Level Vision for Executives. // In: MESA White Paper \#06 (1997).

[30] VDMA: Manufacturing Execution Systems (MES) Kennzahlen (VDMA 66412-1), http://www.vdma.org/ documents/105628/1609825/Download1/63acfab3-45464e1a-b396-1551f53f9c32 (21.02.2016).

[31] Huan, H. S.; Sunil, K.; Sheoran, K. S.; Wang, G. A Review and Analysis of Supply Chain Operations Reference (SCOR) Model. // Supply Chain Manag.: Int. J. 9, 1(2004), pp. 23-29. https://doi.org/10.1108/13598540410517557

[32] Kirikova, M.; Buchmann, R.; Aurelian Costin, R. Joint Use of SCOR and VRM. Perspectives in Business Informatics Research. // In: Aseeva, N.; Babkin, E.; Kozyrev, O. (eds.) Business Informatics Research, vol. 128, pp. 111-125. Springer-Verlag, Berlin/Heidelberg, Germany (2012). https://doi.org/10.1007/978-3-642-33281-4_9

[33] Perdicoúlis, A.; Glasson, J. The Use of Indicators in Planning: Effectiveness and Risks. // Plan. Pract. Res. 3, (2011), pp. 349-367. https://doi.org/10.1080/02697459.2011.580115

[34] Tseng, M. L.; Wu, K. J.; Nguyen, T. T. Information Technology in Supply Chain Management: A Case Study. // Procedia - Soc. Behav. Sci. 25, (2011), pp. 257-272. https://doi.org/10.1016/j.sbspro.2011.10.546

[35] Madapusi, A.; D'Souza, D. The Influence of ERP System Implementation on the Operational Performance of an Organization. // Int. J. Inf. Manag. 32, 1(2012), pp. 24-34. https://doi.org/10.1016/j.jijnfomgt.2011.06.004

[36] Arunagiri, P.; Gnanavelbabu, A. Identification of High Impact Lean Production Tools in Automobile Industries Using Weighted Average Method. // In: M. Anthony Xavior M. A.; Yarlagadda, P. K. (eds.) $12^{\text {th }}$ Global Congress on Manufacturing and Management, GCMM 2014, Elsevier, 97, (2014), pp. 2072-2080.

https://doi.org/10.1016/j.proeng.2014.12.450

\section{Authors' addresses}

\section{Simon Oman}

Polycom Škofja Loka

Poljane nad Škofjo Loko 76

4223 Poljane nad Škofjo Loko, Slovenia

E-mail: simon.oman@polycom.si

Robert Leskovar, PhD

Software Quality and Testing Laboratory

Faculty of Organizational Sciences University of Maribor 4000 Kranj, Slovenia

E-mail: robert.leskovar@fov.uni-mb.si

\section{Bojan Rosi, PhD}

Faculty of Logistics University of Maribor

3000 Celje, Slovenia

E-mail: bojan.rosi@uni-mb.si

\section{Alenka Baggia, PhD}

Software Quality and Testing Laboratory

Faculty of Organizational Sciences University of Maribor 4000 Kranj, Slovenia

E-mail: alenka.baggia@fov.uni-mb.si 